Paulina Legutko-Kobus

\title{
ROLA LIDERA LOKALNEGO W ROZWOJU GMINY
}

\section{Wprowadzenie}

Zyskujący na znaczeniu nurt lokalności (małych ojczyzn, ojczyzn prywatnych), budowa i rozwój społeczeństwa obywatelskiego, wdrażanie zasady partycypacji społecznej sprawiają, że badacze poświęcają coraz więcej uwagi roli, jaką w społecznościach lokalnych pełnią (lub pełnić powinni) liderzy - animatorzy rozwoju w społecznościach lokalnych. Ponadto należy zauważyć, że w pracach naukowych dotyczących procesów rozwoju dużo uwagi poświęca się ogólnie rozumianemu czynnikowi ludzkiemu w procesach rozwojowych, w tym szczególnie kapitałowi społecznemu i intelektualnemu.

Wychodząc z tych założeń, autorka stara się odpowiedzieć na pytanie dotyczące roli lidera (zarówno indywidualnego, jak i zbiorowego) w procesach rozwoju lokalnego, głównie w programowaniu rozwoju lokalnego i koncepcji organizacji uczącej się.

$\mathrm{Na}$ wstępie warto zauważyć, że tematyka podejmowana w opracowaniu charakteryzuje się dużą specyfiką w zależności od rodzaju gminy i charakterystyki społeczności lokalnej, w tym głównie liczby mieszkańców i stopnia zżycia się danej społeczności. Dla ujednolicenia rozpatrywanego problemu (przede wszystkim w warstwie szczegółowej, praktycznej) w centrum zainteresowania autorki znalazły się gminy wiejskie, które zdecydowanie przeważają pośród wszystkich gmin w Polsce ${ }^{1}$. Polskie regiony mają w różnym stopniu wiejski charakter. Najmniej wiejskie, wedle danych GUS, jest województwo śląskie, którego 69,3\% powierzchni stanowią obszary

1 Wedle danych GUS na 2478 gmin ogółem w Polsce 1586 stanowią gminy wiejskie, zaś miejscowości wiejskie to 54135 (dane na 31 grudnia 2008 r.). Rocznik Statystyczny Rzeczypospolitej Polskiej 2009, GUS, Warszawa 2010, s. 78, www.stat.gov.pl/cps/rde/xbcr/gus/PUBL_rs_rocznik_statystyczny_rp_2009. pdf (27.11.2010). W opracowaniu autorka odnosić się będzie do własnego doświadczenia wynikającego z obserwacji uczestniczącej z pracy nad dokumentami w małych gminach wiejskich, liczących około 5 tys. mieszkanców. 
wiejskie zamieszkałe przez 21,4\% ludności, najbardziej wiejskie są województwa na tzw. ścianie wschodniej, gdzie 95\% i więcej stanowią obszary wiejskie.

Należy równocześnie wskazać, że obszary o charakterze wiejskim w Polsce nie są jednorodne. Na podstawie prowadzonych badań wyróżnia się pięć podstawowych klas funkcjonalnych wiejskich jednostek terytorialnych o przewadze: 1) funkcji rolniczych, 2) leśnictwa, 3) funkcji turystyczno-wypoczynkowych, 4) funkcji mieszkalnych i usługowo-handlowych, 5) funkcji mieszkaniowych. Najliczniej reprezentowane w całym kraju są gminy wiejskie o przewadze funkcji rolniczych, zdecydowanie dominują na wschodzie Polski. Gminy te nie stanowią jednolitej grupy, gdyż rolnictwo na ich obszarach należy do różnych typów - od tradycyjnego do rynkowego, $\mathrm{z}$ różnym poziomem zatrudnienia i wydajności ${ }^{2}$.

Funkcjonalne zróżnicowanie gmin wiejskich pociąga za sobą także duże zróżnicowanie społeczne. O ile w rozwiniętych krajach Europy Zachodniej obserwuje się zmniejszanie dystansu społecznego pomiędzy wsią a miastem, o tyle w Polsce różnice te są znaczne, choć nie wszędzie. Obszary wiejskie znajdujące się w zasięgu aglomeracji pod względem społeczno-gospodarczym nie są istotnie różne od miast ${ }^{3}$. Dodatkowo na zróżnicowanie rozwoju gmin wiejskich w Polsce mają wpływ czynniki historyczne, jeszcze z epoki zaborów. Jak wskazują badacze polskiej wsi, coraz większe zróżnicowanie obszarów wiejskich rysuje się na osi centrum - peryferie.

Tak zróżnicowana przestrzeń wiejska (pod względem funkcji, stopnia rozwoju społeczno-gospodarczego, bogactw naturalnych, uwarunkowań kulturowych i historycznych) to także olbrzymie zróżnicowanie pod względem kapitału społecznego, rozumianego jako zaangażowanie obywatelskie we wspólnocie (ujęcie R. Putnama), a tym samym zróżnicowane typy liderów lokalnych.

\section{Charakterystyka społeczeństwa polskiego pod względem aktywności społecznej}

$\mathrm{Na}$ kanwie zarysowanej problematyki rozwoju gmin wiejskich rodzą się pytania: Czy liderzy lokalni są potrzebni? Jakie powinni pełnić role? Czy w społeczeństwie demokratycznym nie wystarczą procesy udziału w decyzjach gwarantowane przez prawo? Żeby odpowiedzieć na tak zarysowany problem badawczy dokonano

2 J. Bański, K. Czapiewski, Identyfikacja i ocena czynników sukcesu społeczno-gospodarczego na obszarach wiejskich. Ekspertyza, Zespół Badań Obszarów Wiejskich, IGiPZ PAN, Warszawa, listopad 2008, s. 9.

3 Ibidem, s. 15 
analizy zaangażowania społeczeństwa polskiego w działania związane z rozwojem i podejmowaniem decyzji.

Jak wskazują wszystkie prowadzone badania, Polacy jako społeczeństwo charakteryzują się niskim poziomem zaangażowania w pracę społeczną i niskim poziomem aktywności społecznej, co może wynikać z deficytu zaufania. Nie jest to jednak trend charakterystyczny tylko dla Polski. Wielu naukowców i ekspertów uważa, że nawet w krajach takich jak Kanada, Stany Zjednoczone, Szwecja czy Wielka Brytania (czyli o najlepiej rozwiniętym ustroju demokratycznym) zaufanie maleje. Literatura naukowa nie wiąże zazwyczaj tego problemu z zagadnieniem wiarygodności ${ }^{4}$. Spadek zaufania, a ściślej przekonania do rządów (na który wskazują badania i sondaże) łączy się raczej ze zmniejszaniem kapitału społecznego ${ }^{5}$.

Ponadto w Polsce, podobnie jak w innych krajach byłego bloku wschodniego, obserwuje się niski poziom i jakość kapitału społecznego. Wskaźnik zaufania społecznego (interpersonalnego) jest także na niskim poziomie, ale w ostatnim czasie wykazał niewielką tendencję wzrostową. Badania prowadzone w ramach Diagnozy społecznej wskazują na wzrost tego wskaźnika z 10,5\% w roku 2003 do 13,4\% w roku $2009^{6}$. Z całą pewnością ten zaobserwowany wzrost należy uznać za korzystną tendencję, ale w krajach skandynawskich, takich jak Norwegia czy Dania, wskaźnik ten jest nawet czterokrotnie wyższy.

Ważny jest nie tylko ogólny wskaźnik zaufania społecznego, ale także jego rozkład, czyli to, komu głównie ufamy. Komunikat z badań CBOS dotyczących zaufania społecznego ${ }^{7}$ (z marca 2010 r.) wskazuje, że Polacy:

- najbardziej ufają swojej najbliższej rodzinie (96\%), znajomym (90\%), dalszym krewnym (87\%), współpracownikom (84\%),

- nieograniczonym zaufaniem obdarzają właściwie tylko najbliższą rodzinę (do znajomych nieograniczone zaufanie deklaruje tylko 22\%, a do współpracowników 18\%),

- ufają organizacjom charytatywnym, takim jak: Wielka Orkiestra Świątecznej Pomocy (88\%), Caritas (82\%), PCK (78\%),

- posiadają ograniczone zaufanie w stosunku do rządu, Sejmu, partii politycznych, związków zawodowych i telewizji; co ciekawsze, to zaufanie spada gwałtownie np. w stosunku do rządu o 25 pkt. w porównaniu z 2008 r.,

\footnotetext{
4 R. Hardin, Zaufanie, przekład A. Gruba, Wydawnictwo Sic!, Warszawa 2009, s. 8.

5 Ibidem, s. 83.

6 Diagnoza społeczna 2009. Warunki i jakość życia Polaków. Raport, red. J. Czapiński, T. Panek, www. diagnoza.com/pliki/raporty/Diagnoza_raport_2009.pdf, s. 271-272 (20.11.2010).

7 Zaufanie społeczne, komunikat $\mathrm{z}$ badań CBOS, BS29/2010, marzec 2010, www.cbos.pl/SPISKOM. POL/2010/K_029_10. PDF (18.12.2010).
} 
- darzą stosunkowo dużym zaufaniem Kościół rzymskokatolicki (ufa mu 78\% ankietowanych ${ }^{8}$, wojsko (76\%), harcerstwo (68\%), policję (63\%), Unię Europejską (60\%), ONZ (60\%) oraz NATO (59\%),

- mają w większości zaufanie do władz lokalnych swojego miasta/gminy (55\%), choć jest to o 13 pkt. mniej niż w badaniu z 2008 r.,

- nie najlepiej przedstawia się wskaźnik zaufania do społeczników lokalnych - ufa im $60 \%$, z czego jedynie 10\% w sposób zdecydowany; należy także podkreślić, że sporo respondentów (29\%) ma problem z określeniem poziomu zaufania do lokalnych społeczników, co najprawdopodobniej wynika z nieznajomości takich osób; pozytywne jest to, że zdecydowaną nieufność w stosunku do społeczników deklaruje tylko $11 \%$ badanych.

Niski stopień zaufania do innych niż najbliższa rodzina podmiotów, jak podkreśla P. Sztompka, jest problemem, gdyż zaufanie daje możliwość zdobywania doświadczeń i podejmowania działań ${ }^{9}$.

Cytowane badania wskazują jednoznacznie, że zaufanie wiąże się z działalnością obywatelską. O ile zaufanie w sferze prywatnej w ostatnich latach (2002-2010) wykazuje w miarę stabilny poziom, o tyle sukcesywnie spada liczba osób angażujących się w pracę społeczną. W roku 2007 społecznicy stanowili 31\% dorosłych obywateli, a dwa lata wcześniej było to $36 \%$. W tym samym czasie zaledwie $4 \%$ osób deklarowało, że pracuje w organizacjach charytatywnych. Należy także zauważyć, że organizacje tzw. trzeciego sektora są mocno rozdrobnione, często wykazują fikcyjną działalność, zaś ich liczba wykazuje duże zróżnicowanie regionalne ${ }^{10}$. Najwięcej stowarzyszeń i fundacji zarejestrowanych jest w regionach: mazowieckim, śląskim, wielkopolskim i małopolskim, zaś najmniej w województwach: opolskim, świętokrzyskim, podlaskim i lubuskim. W roku 2008 w Polsce zarejestrowane było w rejestrze REGON 58237 stowarzyszeń i ponad 9000 fundacji. Tylko niewiele ponad połowa z nich była aktywna, $10 \%$ nie prowadziło żadnych działań. Z badań prowadzonych przez Stowarzyszenie Klon/Jawor wynika, że ponad 35\% wszystkich organizacji w Polsce działa w miastach siedzibach województw, a prawie połowa w miastach powyżej 100 tys. mieszkańców. W ostatnich latach można zauważyć także gwałtowny spadek odsetka osób przynależących do stowarzyszeń, w roku 1989 wynosił on 30,5\%, a w roku 2007 już tylko $15 \%{ }^{11}$.

8 Ostatnie wydarzenia, szczególnie spór o krzyż przed pałacem prezydenckim, wyraźnie wpłynęły na te wyniki, w czerwcu 2010 r. $64 \%$ deklarowało zaufanie do Kościoła, a we wrześniu 54\%. Badanie było przeprowadzone na reprezentatywnej próbie 1041 osób dorosłych. Podaję za „Dziennikiem Wschodnim” 20 09.2010, wydanie internetowe, www.dziennikwschodni.pl/apps/pbcs.dll/article?AID=/20100920/KRAJSWIAT/474815639 (25.09.2010).

9 P. Sztompka, Zaufanie. Fundament społeczeństwa, Wydawnictwo Znak, Kraków 2007, s. 308.

10 Podaję za Stowarzyszeniem Klon/Jawor, www.civicpedia.ngo.pl (26.11.2010).

${ }^{11}$ Diagnoza społeczna 2009..., op.cit., s. 272 (15.11.2010). 
Jak wskazuje powyższa analiza, Polacy charakteryzują się raczej małym stopniem zaangażowania w działalność społeczną, co wynika m.in. z: braku osób gotowych bezinteresownie włączyć się $\mathrm{w}$ działanie organizacji pozarządowych i postawy homo sovieticus, objawiającej się wycofaniem z udziału w życiu publicznym ${ }^{12}$. Wydaje się, że właśnie zachowania typu homo sovieticus stanowią podstawową barierę i, co istotniejsze, są niezwykle trudne do przezwyciężenia, gdyż oznaczają potrzebę zmiany mentalności.

O postawie całkowitego wycofania $\mathrm{z}$ życia publicznego i uczestniczenia w procesach decyzyjnych może świadczyć m.in. udział w wyborach, a konkretnie niska frekwencja wyborcza. W tabelach 1-5 zaprezentowano frekwencję wyborczą we wszystkich typach wyborów w Polsce od roku 1989.

Tabela 1. Frekwencja w wyborach prezydenckich (w \%)

\begin{tabular}{|l|l|l|l|l|c|}
\hline \multicolumn{1}{|c|}{ Rok wyborów } & $\mathbf{1 9 9 0}$ & $\mathbf{1 9 9 5}$ & $\mathbf{2 0 0 0}$ & $\mathbf{2 0 0 5}$ & $\mathbf{2 0 1 0}$ \\
\hline Frekwencja & 60,63 & 64,70 & 61,12 & 49,74 & $54,9455,31$ \\
II tura & 53,40 & 68,23 & & 50,99 & \\
\hline
\end{tabular}

Źródło: zestawienie na podstawie danych PKW, www.pkw.gov.pl (12.12.2010).

Należy pamiętać, że w tabeli 1 zaprezentowane zostały uśrednione wyniki dla całej Polski. Analiza przestrzennych danych wskazuje wyraźnie, że istnieje nie tylko różnica regionalna, ale i różnica między obszarami miast (szczególnie dużych) i obszarami wiejskimi, które charakteryzuje nie tylko w tym typie wyborów niższa frekwencja wyborcza.

Tabela 2. Wybory parlamentarne - frekwencja w latach 1989-2007 (w \%)

\begin{tabular}{|l|l|l|l|l|l|l|l|}
\hline \multicolumn{1}{|c|}{ Rok wyborów } & $\mathbf{1 9 8 9}$ & $\mathbf{1 9 9 1}$ & $\mathbf{1 9 9 3}$ & $\mathbf{1 9 9 7}$ & $\mathbf{2 0 0 1}$ & $\mathbf{2 0 0 5}$ & $\mathbf{2 0 0 7}$ \\
\hline $\begin{array}{l}\text { Frekwencja } \\
\text { II tura }\end{array}$ & $\mathbf{6 2 , 7 0}$ & $\mathbf{4 3 , 2 0}$ & $\mathbf{5 2 , 1 3}$ & $\mathbf{4 7 , 9 3}$ & 46,29 & $\mathbf{4 6 , 2 9}$ & $\mathbf{5 3 , 8 8}$ \\
\hline
\end{tabular}

Źródło: zestawienie na podstawie danych PKW, op.cit. (10.12.2010).

Należy zauważyć, że tak jak w poprzednio omawianych wynikach zachodzi dość duże zróżnicowanie we frekwencji w zależności od rodzaju obszaru zamieszkania. W roku 2007 w wyborach do Sejmu w mieście frekwencja wyborcza wynosiła 58,75\% (w Warszawie najwięcej ze wszystkich miast, bo 73,44\%, zaś dzielnicą,

12 W. Misztal, Szanse i bariery rozwoju społeczeństwa obywatelskiego $w$ Polsce, w: Społeczeństwo obywatelskie. Modele teoretyczne i praktyka społeczna, red. E. Balawejder, Wydawnictwo KUL, Lublin 2007, s. 127. 
w której oddano najwięcej głosów, był Ursynów, gdzie frekwencja wyborcza wyniosła $\left.79,74 \%{ }^{13}\right)$. Na obszarach wiejskich frekwencja wyniosła $45,27 \%{ }^{14}$.

Wydawać by się mogło, że skoro sprawy ogólne mniej nas interesują jako społeczeństwo, to może chociaż sprawy wyborów lokalnych są w stanie zainteresować zdecydowaną większość społeczeństwa. Tymczasem, jak wskazują dane zestawione w tabeli 3 , frekwencja w wyborach lokalnych nie przekroczyła do tej pory $50 \%$. Nawet stosunkowo wysoka frekwencja w wyborach prezydenckich w $2010 \mathrm{r}$. nie przełożyła się na wyższą niż do tej pory frekwencję w wyborach samorządowych.

Tabela 3. Wybory lokalne - frekwencja (w \%)

\begin{tabular}{|l|c|c|c|c|}
\hline \multicolumn{1}{|c|}{ Rok wyborów } & $\mathbf{1 9 9 8}$ & $\mathbf{2 0 0 2}$ & $\mathbf{2 0 0 6}$ & $\mathbf{2 0 1 0}$ \\
\hline Frekwencja & 48 & 44,23 & 45,99 & 47,32 \\
Il tura & & & 39,56 & 35,31 \\
\hline
\end{tabular}

Źródło: zestawienie na podstawie danych PKW, op.cit. (12.12.2010).

Zróżnicowanie frekwencji w tym typie wyborów dotyczyło przede wszystkim poszczególnych regionów. W ostatnich wyborach w $2010 \mathrm{r}$. w I turze frekwencja wahała się od 53,59\% (woj. świętokrzyskie) do 42,94\% (woj. śląskie). W II turze także najwyższa frekwencja została odnotowana w województwie świętokrzyskim (41,24\%), a najniższa w regionie śląskim $(29,45 \%)$.

Tabela 4. Udział w referendach ogólnopolskich (w \%)

\begin{tabular}{|c|c|c|c|c|}
\hline $\begin{array}{c}\text { Rok } \\
\text { i referendum }\end{array}$ & $\begin{array}{c}1996 \\
\text { uwłaszczeniowe }\end{array}$ & $\begin{array}{c}1996 \\
\text { prywatyzacyjne }\end{array}$ & $\begin{array}{c}1997 \\
\text { konstytucyjne }\end{array}$ & $\begin{array}{c}2003 \\
\text { akcesyjne }\end{array}$ \\
\hline Frekwencja & 32,40 & 32,44 & 42,86 & 58,85 \\
\hline
\end{tabular}

Źródło: zestawienie na podstawie danych PKW, op.cit. (12.12.2010).

Jak wskazują dane zestawione w tabeli 4, tylko w przypadku jednego referendum została przekroczona $50 \%$ frekwencja - było to referendum akcesyjne, które pod względem frekwencji także charakteryzowało się zróżnicowaniem regionalnym. Najwyższa frekwencja została odnotowano w województwie dolnośląskim $(60,18 \%$, zróżnicowanie wewnątrzregionalne - miasto Wrocław 67,34\%, zaś powiat górowski 50,67\%). Najniższą frekwencję w tym referendum odnotowano w województwie świętokrzyskim i wynosiła ona 52,14\% (w tym w mieście Kielce 65,39\%, a w powiecie

13 Tak wysoka frekwencja zaskoczyła nawet PKW, na Ursynowie w wielu punktach do głosowania zabrakło kart i dowożono je z innych dzielnic, dlatego głosowanie przedłużono do 22,00.

${ }^{14}$ Wszystkie szczegółowe dane dotyczące frekwencji wyborczej podawane są na podstawie informacji dostępnych na stronie internetowej Państwowej Komisji Wyborczej. 
kazimierskim jedynie 41,89\%). Charakterystyczne jest to, że w dużych miastach, bez względu na region, frekwencja była stosunkowo wysoka.

$\mathrm{Na}$ stronie PKW brak danych dotyczących referendów lokalnych, jednak z doświadczeń i obserwacji uczestniczącej autorki wynika, że gminy sięgają do tej instytucji demokracji bezpośredniej niezwykle rzadko, ponieważ w niewielu przypadkach udaje się uzyskać zadowalającą frekwencję.

Jak wskazują dane zestawione w tabeli 5, wybory do Parlamentu Europejskiego charakteryzuje w Polsce najniższa frekwencja, ale i w tym przypadku zróżnicowanie regionalne i w podziale miasto - wieś jest znaczne.

Tabela 5. Wybory do Parlamentu Europejskiego - frekwencja (w \%)

\begin{tabular}{|l|l|l|}
\hline Rok wyborów & $\mathbf{2 0 0 4}$ & $\mathbf{2 0 0 9}$ \\
\hline Frekwencja & 20,87 & 24,53 \\
\hline
\end{tabular}

Źródło: zestawienie na podstawie danych PKW, op.cit. (10.12.2010).

W wyborach do Parlamentu Europejskiego w roku 2009 frekwencja w miastach wynosiła 28,51\% (w Warszawie aż 43,44\%), zaś na obszarach wiejskich tylko 17,63\%. Najwyższą frekwencję odnotowano w Podkowie Leśnej (50,86\%).

Przedstawione dane na temat partycypacji wyborczej z jednej strony informują nas o zaangażowaniu Polaków w sprawy polityczne, z drugiej, co ważniejsze dla poruszanego tematu, o ogólnej aktywności obywatelskiej i jej rozkładzie przestrzennym. Konkluzja jest raczej przygnębiająca. Niewielu z obywateli interesuje, kto i jak nimi rządzi, a sprawy im najbliższe (wybory lokalne) interesują ich jeszcze mniej niż wybory do krajowego parlamentu czy prezydenckie. Potrafimy, jako społeczeństwo, wykazać się jednorazowym zrywem, kiedy ważą się sprawy dla nas istotne (jak choćby w przypadku referendum akcesyjnego), ale zdecydowana większość obywateli nie uczestniczy w decyzjach politycznych ważnych na szczeblu lokalnym, krajowym czy UE. Ponadto należy zauważyć, że we wszystkich typach wyborów znacznie niższa frekwencja odnotowywana jest na obszarach wiejskich niż w miastach, szczególnie dużych powyżej 250 tys. mieszkańców.

Problemem, który także należałoby w tym kontekście poruszyć, jest z pewnością niestabilność zachowań wyborczych (swe zachowania między wyborami w Polsce zmienia znacznie więcej obywateli niż w innych demokracjach: wielu przechodzi od głosowania do absencji lub odwrotnie, wielu zmienia partyjne preferencje). Prowadzone badania jednoznacznie wskazują, że jesteśmy jednym z najbardziej niestabilnych wyborczo krajów świata. Niestabilność zachowań wyborczych w największym stopniu obserwowana jest na obszarach wiejskich i jest to proces pogłębiający się. 
W 1997 r. 38\% wśród niestabilnych wyborców stanowili mieszkańcy wsi, a w 2007 r. już 45\% (dla porównania w tych samych latach wśród mieszkańców miast powyżej 500 tys. mieszkańców było to odpowiednio $12,7 \%$ i $9 \%)^{15}$.

Jeśli nasze zaangażowanie w sprawy tak ważne jak udział w demokratycznych wyborach (także władz lokalnych) jest tak dramatycznie niskie, to czy możemy jako obywatele małych ojczyzn wymagać, by władza lokalna podejmowała dobre decyzje dla całej wspólnoty terytorialnej, czy tylko dla tej części społeczności, która bierze aktywny udział w życiu obywatelskim. Coraz częściej w badaniach, a także w praktycznych projektach wdrożeniowych podnoszony jest problem udziału społeczności lokalnych w podejmowaniu decyzji, procedur konsultacji społecznych dostosowanych do charakteru konkretnego terytorium. Podkreśla się znaczenie deliberacji, a konkretnie sondaży deliberatywnych w procesach podejmowania decyzji związanych z rozwojem lokalnym. Według J. Fishkina dzięki sondażom deliberatywnym możliwe jest dogłębne poznanie wszystkich punktów widzenia, opinii ludzi w konkretnej sprawie ${ }^{16}$. W tej metodzie widoczna jest chęć uzasadnienia roli debaty publicznej w konsultacjach społecznych. Zdaniem autorki sondaż deliberatywny jest z pewnością najbardziej zaawansowaną metodą partycypacji, nie zawsze jednak możliwą do wykorzystania. Wadą tego typu sondażu, dość istotną z punktu widzenia małych gmin wiejskich, mogą być koszty związane z zatrudnieniem ekspertów.

W związku z niewielkim zaangażowaniem społeczności wiejskich w aktywność obywatelską (jak wykazują zestawione dane) i niewielkim zainteresowaniem bezpośrednią demokracją wyrażającą się udziałem w referendach, niską wiedzą (w tej grupie gmin) z zakresu sondaży deliberatywnych (gminy, z którymi współpracuje autorka w ogóle nie znają tego mechanizmu) warto zastanawiać się nad możliwością wykorzystania do konsultacji i zasięgania opinii w procesach decyzyjnych i rozwojowych przedstawicieli społeczności lokalnych, zwanych liderami, mentorami itp.

\section{Lider lokalny - czyli kto?}

Jak wskazano, Polacy niezbyt chętnie angażują się społecznie i partycypują w procesach decyzyjnych. Tymczasem prawo, a także implementacja zasad rozwoju zrównoważonego wymaga podejmowania decyzji w szerokiej procedurze partycypacyjnej.

${ }^{15}$ Niestabilność wyborcza w Polsce, red. M. Cześnik, Fundacja Instytut Spraw Publicznych, Warszawa 2010, s. 8, 45, www.isp.org.pl (05.01.2011).

${ }^{16}$ Cytuję za wypowiedzią zamieszczoną na stronie http://civicpedia.ngo.pl/ngo/501211.html\# (20.11.2010). 
Udział społeczeństwa w podejmowaniu decyzji regionalnych i lokalnych to jedne z czynników społecznych rozwoju ${ }^{17}$.

Na gruncie socjologii zdolność mieszkańców do organizacji oraz mobilizacji środków pozwalających osiągnąć uzgodnione i zaakceptowane przez większość cele to zasoby lokalne. Teoria zasobów lokalnych zakłada dwie formy uczestnictwa obywateli w życiu społeczności lokalnej ${ }^{18}$ :

- słabszą, czyli postrzeganie siebie jako członka wspólnoty lokalnej biorącego udział w jej życiu, ale bez zbytniego „wychylania się” (angażowania),

- mocniejszą, zakładającą, że podmiot lokalny mający moc sprawczą i wpływ na sprawy wspólnoty to my (mieszkańcy); taką formę zaangażowania wykazują właśnie lokalni liderzy określani także jako lokalne elity.

Biorąc pod uwagę powyższe ustalenia, tym ważniejsze wydaje się rozpoznanie w warunkach gminy lokalnych liderów, społeczników, poprzez których można dotrzeć do społeczności lokalnej lub którzy są wyrazicielami opinii poszczególnych grup społecznych, bowiem rozwój lokalny w dużej mierze zależy od stopnia akceptacji społecznej dla podejmowanych działań.

\subsection{Cechy liderów lokalnych}

Zdaniem P. Weryńskiego lokalni liderzy to zbiorowy podmiot integrujący, posiadający kompetencje intelektualne, wiedzę, określoną samoświadomość obywatelską oraz stanowiący grupę odniesienia dla mieszkańców ${ }^{19}$. I. Krukowska-Szopa i A. Ruszlewicz, wskazują, że liderzy lokalni to ludzie znani, cieszący się autorytetem, z których zdaniem liczy się społeczność lokalna ${ }^{20}$. Lider to osoba, która inspiruje, przekonuje, motywuje i oddziałuje na innych, a także toruje drogę zmianom ${ }^{21}$. Warto zastanowić się bliżej nad fenomenem liderów, nad tym, jakie cechy sprawiają, że chętniej słuchamy jednych osób, a innych nie.

W literaturze dotyczącej problematyki liderów lokalnych stosuje się rozróżnienie na liderów formalnych (głównie są to osoby umocowane w strukturach

17 W. Kosiedowski, Zarządzanie rozwojem regionalnym i lokalnym, w: Gospodarka regionalna i lokalna, red. Z. Strzelecki, Wydawnictwo Naukowe PWN, Warszawa 2008, s. 235; por. także J. Hausner, Zarzq̨dzanie publiczne, Wydawnictwo Naukowe Scholar, Warszawa 2008, s. 384-388.

18 P. Weryński, Typologia uczestnictwa obywatelskiego polskich liderów lokalnych, w: Społeczne aspekty zrównoważonego rozwoju wsi w Polsce. Partycypacja lokalna i kapitał społeczny, red. H. Podedworna, R. Ruszkowski, Wydawnictwo Naukowe Scholar, Warszawa 2008, s. 179.

19 Ibidem, s. 180

20 I. Krukowska-Szopa, A. Ruszlewicz, Jak budować program ekorozwoju w gminie wiejskiej, Fundacja Ekologiczna Ziemi Legnickiej Zielona Akcja, Jelenia Góra-Legnica 1998, s. 41.

$21 \mathrm{Ta}$ definicja zamieszczona jest na stronie informacyjnej projektu Kompetentna gmina, www. bfkk.pl/libs/ckfinder/userfiles/files/administracja_publiczna/Przyw\%C3\%B3dztwo\%20w\%20ZRL.pdf (23.11.2010). 
władzy samorządowej) i nieformalnych (przedstawiciele trzeciego sektora, autorytety moralne, twórcy ludowi itp. $)^{22}$. Wydaje się, że w warunkach polskich liderami mogą być przedstawiciele instytucji, do których mamy zaufanie (dobrym przykładem mogą być proboszczowie, szczególnie na obszarach wiejskich, którzy cieszą się dużym zaufaniem i posłuchem społecznym - najczęściej większym niż kościół hierarchiczny). Jeśli nie autorytet instytucji, którą reprezentuje lider, to cechy osobnicze mogą sprawiać, że ktoś zostaje liderem. I. Majewska-Opiełka uważa, że lidera powinny cechować ${ }^{23}$ :

- poczucie własnej wartości, ale wynikające z wiedzy na temat swoich mocnych stron oraz możliwości ich wykorzystania,

- pełna odpowiedzialność za własne życie (to podejmowane decyzje, a nie okoliczności decydują o tym, w którym miejscu jestem),

- samodzielność i spójność - odpowiedzialność za siebie, a także zgodność słów z czynami i myślami,

- pozytywne myślenie i przekonanie, że dóbr starczy dla wszystkich (nazywane także poczuciem obfitości),

- współzależność, polegająca na przeświadczeniu, że jestem częścią społeczności lokalnej, i umiejętność współpracy z innymi ludźmi,

- zdolność i wola ciągłego uczenia się,

- umiejętność tworzenia wizji przekazania swoich pomysłów i przekonywania do nich,

- intuicja, nie mniej ważna od pozostałych cech, ona czasem stanowi o tym czymś (o charyzmie), za czym idą ludzie.

Lider lokalny powinien posiadać także cechy przywódcy, który porwie do działania. Nie chodzi jednak o przywództwo rozumiane jako proces wpływu na ludzi, ale umiejętność wyzwalania siły do działania umożliwiającej dążenie do wyznaczonego celu. Przywódcę, w takim ujęciu, powinna więc cechować ${ }^{24}$ :

- ciekawość (bo musi słuchać ludzi, szczególnie tych spoza swojego najbliższego otoczenia),

- kreatywność, rozumiana jako wychodzenie poza przyjęte schematy, ramy, tzw. wychylanie się,

- zdolność do porozumiewania się (komunikatywność), co ważne, komunikowanie musi być czytelne dla odbiorców i do nich dostosowane,

\footnotetext{
22 I. Krukowska-Szopa, A. Ruszlewicz, op.cit.

${ }^{23}$ I. Majewska-Opiełka, jedna z najbardziej znanych trenerek osobistych, autorka m.in. Umysłu lidera, (Wydawnictwo Medium, Warszawa 2008), w którym przedstawia swoje poglądy dotyczące liderów wynikające z długoletniego doświadczenia praktycznego.

${ }^{24}$ L. Iacocca, C. Whitney, Gdzie się podziali ci wszyscy przywódcy?, Dom Wydawniczy Rebis, Poznań 2007, s. 17-21.
} 
- niezłomny charakter (żeby nie tylko wiedzieć, co dobre, ale i robić to, co dobre) i zdrowy rozsądek,

- odwaga, ale rozumiana jako ciągła otwartość do rozmów i negocjacji nawet w najtrudniejszych kwestiach,

- przekonanie do tego, co robi, pewna ideowość (ale rozumiana raczej w duchu platońskim),

- charyzma, która powoduje, że ludzie się identyfikują z przywódcą, chcą za nim iść, - kompetencje.

Lider to także ktoś, kto jest otwarty, empatyczny, kto umie budować wokół siebie zespół, łatwo wzbudza zaufanie i umie rozwiązywać konflikty. Z doświadczeń autorki wynika, że tego nie można się nauczyć. Oczywiście można i należy wzmacniać lokalnych liderów poprzez podnoszenie ich wiedzy i kompetencji (co dzieje się między innymi dzięki wykorzystaniu funduszy europejskich na ten cel), ale szczególnie w społecznościach wiejskich zaufanie zdobywa się poprzez działanie. Coraz częściej podkreśla się także, że rolą lidera jest nie tyle zarządzanie i odpowiedzialność za realizację zadań i osiągnięcie zamierzonego celu, a moderowanie i pobudzanie do działania każdego uczestnika procesu rozwoju.

\subsection{Typy liderów}

W poprzednim podrozdziale przedstawione zostały cechy lidera idealnego, odpowiedzialnego za wspólnotę i świadomego faktu bycia liderem oraz spoczywającej na nim odpowiedzialności. Czy tacy liderzy zdarzają się w środowiskach lokalnych, małych gmin wiejskich? Z obserwacji uczestniczącej, związanej z programowaniem rozwoju gmin wiejskich Lubelszczyzny, z całą stanowczością mogę stwierdzić, że tak, choć być może nie potrafią oni nazwać swoich cech zgodnie z powyższymi wyliczeniami.

Na podstawie badań prowadzonych w gminach Śląska Opolskiego i wschodniej Małopolski P. Weryński wyróżnił trzy typy liderów lokalnych ${ }^{25}$ :

- administrator, koncentrujący swoją działalność na sferze polityczno-samorządowej, którego cechuje ścisła kooperacja z instytucjami państwa,

- partner, którego dominującym obszarem aktywności jest sfera działań gospodarczo-społecznych, a cechuje go niezależny krytycyzm; często prowadzi do wzmacniania kapitału społecznego, ponieważ opiera się na oddolnym, mikrostrukturalnym budowaniu interakcji pomiędzy podmiotami życia społeczno-gospodarczego,

- patron-mentor, związany ze sferą działań społeczno-kulturowych, podkreślający subsydiarność w stosunku do instytucji państwowych; ten typ lidera wiąże

25 P. Weryński, op.cit., s. 189-190. 
się z tradycją inteligenckiego etosu służby publicznej, wolontariatu społecznego; raczej nie przyczynia się (w swojej czystej postaci) do wzmacniania kapitału społecznego i podnoszenia współudziału w procesach decyzyjnych szerszych grup społecznych, może prowadzić do podejmowania decyzji i rozwiązywania problemów ponad głowami zwykłych (nieoświeconych) obywateli.

Każdą jednostkę samorządu lokalnego, w tym gminę wiejską, charakteryzuje swoisty układ liderów, w tym ich typów i roli, jaką chcą i mogą odgrywać. Autorka jest zdania, że ma na to wpływ nie tylko struktura samych liderów, ale przede wszystkim nastawienie do nich reszty społeczności lokalnej. Istotne bowiem jest tworzenie lokalnych, nieformalnych grup wspierających liderów, tworzenie kanałów i sieci komunikacyjnych, a także zwalczenie dość powszechnego przekonania wśród liderów, że doskonale wiedzą, co jest lepsze dla społeczności lokalnej, i nie muszą zasięgać opinii mieszkańców.

Jak wynika z obserwacji uczestniczącej wśród gmin wiejskich, można wyróżnić kilka modeli liderów lokalnych. Można więc wskazać gminy posiadające:

- silnego lidera indywidualnego, formalnego - najczęściej wójta, który zazwyczaj pełni funkcję dłużej niż jedną kadencję; jego podejście do pozostałych liderów lokalnych w dużej mierze zależy od zaplecza, które ma w najbliższym otoczeniu; jeśli w Radzie Gminy zasiadają tzw. liderzy patroni, mentorzy, to raczej do nich ograniczają się konsultacje i demokracja partycypacyjna; jeśli natomiast Rada Gminy składa się z bardziej przypadkowych osób, a wśród liderów lokalnych (poza Radą Gminy) są przedstawiciele społeczności działający na niwie kultury i społeczno-gospodarczej, to partycypacja w procesach rozwojowych ma szerszy wymiar,

- charyzmatycznego lidera lokalnego, który wokół siebie skupia grupę osób i który traktuje cały zespół jako lidera zbiorowego; z takim przypadkiem autorka zetknęła się w jednej gminie, gdzie wójt przed pracą samorządową był menedżerem,

- zbiór w miarę równoprawnych liderów lokalnych z różnych środowisk, którzy w razie potrzeby podejmują wspólne działanie, a na co dzień animują małe grupy wokół siebie (np. biblioteki, koła gospodyń wiejskich, towarzystwa regionalne),

- liderów będących w opozycji do władz samorządowych; to dość skomplikowany przypadek, bo wystarczy wskazać, że ta opozycja może być słuszna i mieć na celu patrzenie na ręce lokalnym włodarzom i mieć podłoże konfliktów lokalnych, nie zawsze merytorycznych, może wynikać także z uprzedzeń np. do mniejszości narodowych ${ }^{26}$.

Wśród liderów lokalnych na obszarach wiejskich coraz istotniejszą role odgrywają kobiety. Można zauważyć, że istnieje tendencja do wzmacniania roli kobiet

${ }^{26} \mathrm{~W}$ takim przypadku należałoby rozważyć, jaki wpływ na rozwój lokalny ma tzw. ciemny kapitał społeczny. 
w strukturach lokalnych. Jako przykład można wskazać prowadzoną przed wyborami w roku 2010 kampanię medialną i szkolenia prowadzone dla kandydatek w wyborach samorządowych ${ }^{27}$. Jak wskazują badania, w ostatnich latach mamy coraz większą grupę sołtysek, radnych, wójtów (wydaje się nawet, że parytet znacznie szybciej zostanie osiągnięty w gminach wiejskich niż w Sejmie). Największe badanie (do jakiego udało się dotrzeć autorce) skierowane do lokalnych liderów kobiet przeprowadzone zostało w 2005 r. i objęło 86 sołtysek z całej Polski. W raporcie Nowe szanse na polskiej wsi opracowanym w 2005 r. stwierdzono, że na wsi to kobiety planują i rozporządzają, a mężczyznom pozostaje realizować ich plany ${ }^{28}$. Analiza wyników konkursu na „Sołtysa Roku”, ogłaszanego przez „Gazetę Sołecką", pozwala także na stwierdzenie, że praca kobiet na rzecz społeczności lokalnej jest coraz częściej doceniana (w tabeli 6 zestawiono laureatów konkursu z lat 2007-2009²9).

Tabela 6. Laureaci konkursu Sołtys Roku w latach 2007-2009

\begin{tabular}{|l|c|l|c|}
\hline \multicolumn{1}{|c|}{ Rok } & $\mathbf{2 0 0 7}$ & $\mathbf{2 0 0 8}$ & $\mathbf{2 0 0 9}$ \\
\hline $\begin{array}{l}\text { Liczba laureatów } \\
\text { (w tym kobiet) }\end{array}$ & $12(7)$ & $12(5)$ & $13(5)$ \\
& & $\begin{array}{l}\text { przyznano także jedno specjalne wyróżnienie dla sołtyski, } \\
\text { która swój urząd piastowała od 50 lat }\end{array}$ & \\
\hline
\end{tabular}

Źródło: zestawienie na podstawie danych „Gazety Sołeckiej”, www.gazetasolecka.pl/soltysroku.html

W tym miejscu warto podkreślić, że wybór na sołtysa jest bezpośredni, odbywa się na zebraniu wiejskim, w społeczności, gdzie wszyscy się znają, a zaufanie ma kluczowe znaczenie. Może dlatego coraz więcej na tych stanowiskach kobiet?

\section{Lider lokalny a programowanie rozwoju lokalnego}

Programowanie rozwoju $\mathrm{w}$ warunkach gminy wiejskiej należy rozumieć jako proces, którego efektem jest sformułowanie celu i określenie sposobu jego osiągnięcia. Programowanie w praktycznym wymiarze oznacza opracowanie dokumentów gminnych, o różnym horyzoncie czasowym.

27 Informacja o szkoleniach i oferta szkoleń dostępna na stronie Fundacji Rozwoju Demokracji Lokalnej http://www.frdl.org.pl/index.htm (26.10.2010).

${ }^{28} \mathrm{Na}$ podstawie omówienia raportu dostępnego na stronie www.rzeczpospolita.pl/dodatki/plus_ minus_051217/plus_minus_a_10.html (22.11.2010).

${ }^{29}$ Wyniki konkursów dostępne na stronie www.gazetasolecka.pl/soltysroku.html (11.12.2010). Zgodnie z regulaminem konkurs za rok 2010 zakończył się w lutym $2011 \mathrm{r}$. 


\subsection{Miejsce i rola lidera w lokalnej strategii rozwoju}

Opracowanie strategii - dokumentu długookresowego to zdaniem autorki najpełniejsza forma programowania rozwoju w gminie wiejskiej. Podmiotem strategii jest społeczeństwo zamieszkujące określony obszar sklasyfikowany jako przedmiot strategii. Należy zauważyć, że społeczeństwo działa za pośrednictwem swoich demokratycznie wybranych przedstawicieli i nie całe społeczeństwo w strategii będzie odgrywać takie same role ${ }^{30}$. Można więc wskazać w podmiocie strategii podzbiory: tych, którzy mają sformułować strategię i ją wdrażać, i tych, którzy będą uczestniczyć w formułowaniu i wdrażaniu. W takim ujęciu lokalni liderzy mogą stanowić pomost między tymi podzbiorami, gdyż w zależności od tego, $\mathrm{z}$ jakim typem liderów mamy do czynienia, będą albo tylko formułować strategię, albo tylko wdrażać, a chyba największa grupa będzie uczestniczyć w całym procesie, co jest najkorzystniejsze z punktu widzenia rozwoju lokalnego.

Tabela 7. Lokalni liderzy w procesie programowania

\begin{tabular}{|l|l|}
\hline \multicolumn{1}{|c|}{ Etap programowania } & \multicolumn{1}{c|}{ Rola, zadania lokalnych liderów } \\
\hline Diagnoza stanu & $\begin{array}{l}\text { Lokalni liderzy to nieocenione źródło informacji lub ich uzupełniania i aktualizacji. } \\
\text { Włączenie na tym etapie jak największej liczby przedstawicieli różnych środowisk } \\
\text { gwarantuje obiektywizm w zbieraniu danych } \\
\text { i poprawne diagnozowanie podstawowych, aktualnych problemów rozwoju, czyli } \\
\text { odpowiedzi na pytanie o aktualny stan rozwoju gminy. }\end{array}$ \\
\hline Formułowanie wizji i celów & $\begin{array}{l}\text { Ten etap, szczególnie w niewielkich społecznościach gmin wiejskich, wywołuje wiele } \\
\text { emocji, gdyż każdy uważa, że cele ważne dla niego są istotne z punktu widzenia } \\
\text { rozwoju gminy. W wywiadach bezpośrednich mieszkańcy gmin wiejskich często } \\
\text { podkreślają, że radni dbają tylko o swoje ulice, nie interesuje ich całościowe podejście } \\
\text { do gminy. W takim przypadku lider lokalny (także nieformalny), który ma cechy } \\
\text { przywódcy, a głównie charyzmę, umiejętność słuchania, zdrowy rozsądek i umie } \\
\text { wziąć odpowiedzialność za podjęte decyzje, to gwarancja stabilnego } \\
\text { i zaplanowanego rozwoju lokalnego. }\end{array}$ \\
\hline $\begin{array}{l}\text { Mechanizmy realizacji i oceny } \\
\text { (wdrażanie i monitoring) }\end{array}$ & $\begin{array}{l}\text { Na tym etapie lokalni liderzy to swoisty papierek lakmusowy dla władzy gminnej, } \\
\text { która powinna czuć, że partycypacja w programowaniu trwa w sposób ciągły, nie } \\
\text { ma początku ani końca. Dlatego tak istotne jest, żeby wśród liderów lokalnych byli } \\
\text { także ci wywodzący się z nieformalnych struktur, a nie tylko liderzy formalni związani } \\
\text { ze strukturą samorządu. Na etapie wdrażania strategii, poprzez swój autorytet, } \\
\text { lokalni liderzy propagują we własnych środowiskach założenia strategii, ponieważ } \\
\text { są nośnikami informacji na obszarach wiejskich skuteczniejszymi niż papier czy } \\
\text { media elektroniczne*. Ponadto nie do przecenienia jest rola liderów w ewaluacjach, } \\
\text { szczególnie bieżących, które pozwalają korygować, w zależności od stopnia zmian } \\
\text { zachodzących w społeczności lokalnej, wytyczone kierunki rozwoju. }\end{array}$ \\
\hline
\end{tabular}

* Por. J. Kwiatkowski, Partycypacja społeczna i rozwój społeczny, FRDL, Warszawa 2003, s. 16.

Źródło: opracowanie własne.

30 E. Wysocka, J. Koziński, Strategie rozwoju regionalnego i lokalnego po reformie administracyjnej państwa, Difin, Warszawa 2000, s. 13-20. 
W formułowaniu strategii lokalni liderzy formalni, a także przedstawiciele organizacji pozarządowych, lokalni przedstawiciele związków wyznaniowych, twórcy ludowi mogą tworzyć ciała doradcze dla władz gminy (np. konwenty rozwoju, komitety sterujące, które powinny grupować wszystkich liderów lokalnych lub jeśli jest ich niewielu, także osoby, które choć w niewielkim zakresie mają ochotę uczestniczyć w formułowaniu wizji rozwoju).

Powołanie takich ciał doradczych to także doskonały sposób na wzmacnianie roli lokalnych liderów, ponieważ pracują one zazwyczaj w zespołach problemowych. Często osoby, które nie czują się na siłach same wystąpić jako liderzy, stanowią doskonałe zaplecze wspomagające lidera, ale głównie tzw. lidera partnera, ponieważ raczej w przypadku lidera-mentora nie dochodzi do budowania lokalnych sieci wsparcia. W procesie programowania wyróżnić możemy diagnozę, formułowanie wizji i celów oraz mechanizmy realizacji i oceny. Na każdym z tych etapów inną rolę będą odgrywać lokalni liderzy (tabela 7).

\subsection{Lider lokalny a organizacja ucząca się}

Organizacja ucząca się (zdolna do uczenia) to termin, który pierwotnie dotyczył przede wszystkim filozofii zarządzania przedsiębiorstwami - z czasem, jak i inne modele zarządzania, zaczął być stosowany także w stosunku do gmin. Wydaje się, że ten model zarządzania gminami jest szczególnie kompatybilny z wyłanianiem i/lub działaniem liderów lokalnych zarówno indywidualnych, jak i zbiorowych.

Organizację uczącą się definiujemy jako organizację, która ciągle rozszerza swoje możliwości kształtowania własnej przyszłości, a także wspiera uczenie się wszystkich swoich członków (w wymiarze indywidualnym i grupowym). Jest miejscem, gdzie ludzie nieustannie rozwijają swoje zdolności, a zaangażowanie wszystkich pracowników w proces doskonalenia organizacji warunkuje faktyczny rozwój, dzięki któremu organizacja jest zdolna do ciągłej adaptacji w zmieniającym się otoczeniu ${ }^{31}$. Przy takim założeniu rozwój gminy będzie się więc dokonywał poprzez uczenie się i przezwyciężenie problemów utrudniających uczenie się organizacji. Przezwyciężanie (zwalczenie) przeszkód w uczeniu się może nastąpić (zdaniem P. Senge) poprzez pięć dyscyplin: mistrzostwo osobiste, modele myślowe, budowanie wspólnej wizji przyszłości, zespołowe uczenie się i myślenie systemowe ${ }^{32}$.

Na kanwie wcześniejszych ustaleń dotyczących cech, typów i roli liderów lokalnych można się zastanowić, jak rozumieć pięć podstawowych dyscyplin wskazanych

${ }^{31}$ P.M. Senge, Piąta dyscyplina. Teoria i praktyka organizacji uczących się, wyd. V, Oficyna Ekonomiczna, Wolters Kluwer Polska, Kraków 2006, s. 29 i nast.

32 Ibidem, s. 20 i nast. 
przez P. Senge w procesach rozwoju organizacji, jaką jest mała, licząca kilka tysięcy mieszkańców gmina wiejska (tabela 8).

\section{Tabela 8. Pięć dyscyplin organizacji uczącej się a lokalni liderzy}

\begin{tabular}{|c|c|}
\hline $\begin{array}{l}\text { Dyscyplina organizacji } \\
\text { uczącej się }\end{array}$ & Rola, zadania lokalnych liderów \\
\hline Mistrzostwo osobiste & $\begin{array}{l}\text { Mistrzostwo osobiste to umiejętność, biegłość nabywana w toku ćwiczeń. Jest to element } \\
\text { uczenia się jednostki, który obejmuje nie tylko formalne umiejętności zawodowe, ale } \\
\text { i dyspozycje jednostki pozwalające konsekwentnie dążyć do wytyczonych osobistych } \\
\text { celów. Mistrzostwo osobiste jest stanem, którego raczej się nie osiąga, a do którego się, } \\
\text { daży. Można więc je wskazać jako warunek konieczny, ale nie wystarczający do tego, żeby } \\
\text { być liderem lokalnym w ujęciu indywidualnym. }\end{array}$ \\
\hline Modele myślowe & $\begin{array}{l}\text { Modele myślowe to głęboko zakorzenione założenia, uogólnienia czy obrazy, które } \\
\text { wpływają na nasze rozumienie świata i sposób naszego działania. W organizacji mają } \\
\text { wymiar zbiorowy (mówimy wówczas o kulturze organizacji) i wymiar jednostkowy } \\
\text { (dotyczą stereotypów, schematów i sposobów myślenia każdego pracownika, członka } \\
\text { organizacji). Modele myślowe to sposób myślenia każdego pracownika gminy, czy } \\
\text { potencjalnego lidera lokalnego, obejmujący także stereotypy, schematy i ograniczenia, } \\
\text { które często determinują podejmowane decyzje i wpływają na kreowanie przyszłości. } \\
\text { W gminach trudno wprowadzać modele myślowe, które tworzą kulture organizacji, } \\
\text { ponieważ model zarządzania gminami w Polsce jest mocno zbiurokratyzowany. } \\
\text { Dodatkowo zarząązanie gminą jest obarczone w warunkach polskich pewną skaza, gdyż } \\
\text { nie do końca można je rozdzielić od polityki. Należy także zauważyć, że w gminie tylko } \\
\text { wójt jest kadencyjny, inni pracownicy gminy nie są wybierani, w gminach wiejskich bardzo } \\
\text { często stanowią zgrany, sprawdzony zespół, który ma swoje modele porozumiewania się } \\
\text { bez słów. Często także lokalni liderzy formalni, np. radni, są zgraną grupą, która pracuje } \\
\text { ze sobą kilka kadencji. Jak zwracałam wcześniej uwage,, problem porozumiewania się } \\
\text { bez słów może dotyczyć komunikacji pomiędzy liderem lokalnym i jego najbliższym } \\
\text { otoczeniem. Porozumiewanie się bez stów może bowiem doprowadzić do całkowitego } \\
\text { zaniku komunikacji. Warto również w tym miejscu zauważyć, że kultura organizacji } \\
\text { dotycząca porozumiewania się ma także aspekt zewnętrzny, tzn. dotyczący kontaktowania } \\
\text { się z mieszkańcami czy organizacjami spotecznymi. W tym wypadku każda gmina musi } \\
\text { dostosować komunikowanie się do sobie tylko właściwych warunków, które zmieniają } \\
\text { się w czasie, gmina musi więc na te zmiany reagować. Jest to trudne, czessto sygnał do } \\
\text { zmiany strategii w komunikowaniu się może pochodzić np. od organizacji pozarządowych } \\
\text { czy indywidualnego lokalnego lidera (będącego czasem,,uchem" wychwytującym } \\
\text { pierwsze objawy niezadowolenia spotecznego czy też po prostu frustracji mieszkańców } \\
\text { wynikającej z braku dostępu do klarownej informacji np. dotyczącej wydawania pieniędzy } \\
\text { w gminie na inwestycje infrastrukturalne). }\end{array}$ \\
\hline $\begin{array}{l}\text { Budowanie wspólnej wizji } \\
\text { przyszłości }\end{array}$ & $\begin{array}{l}\text { Wizja ma być siłą napędową, która powinna motywować do działania, zarówno } \\
\text { jednostkowego, jak i wspólnego. W przypadku gminy wiejskiej pracownicy i liderzy } \\
\text { lokalni, mieszkający przecież na terenie gminy, powinni się identyfikować z jej wizją. } \\
\text { Ich jednostkowe wizje, własnej przyszłości i kariery, powinny być spójne z wizją gminy. } \\
\text { Wizja bowiem wtedy jest dobra, prawdziwa, jeśli potrafi porwać do działania przynajmniej } \\
\text { znaczną większość pracowników gminy, a lokalni liderzy potrafią się z nią identyfikować, } \\
\text { pracować nad jej realizacją i przekonywać do niej społeczność. } \\
\text { Niekiedy do urzeczywistnienia wizji wystarczy porywający lider, który potrafi skupić } \\
\text { wokół siebie współpracujący z nim zespół. Takim liderem może stać się wójt (o cechach } \\
\text { przywódcy), który doprowadza do osiagnięcia zamierzonych celów, jest swoistym } \\
\text { strażnikiem i gwarantem osiąganej wizji. Liderem, gwarantem urzeczywistnienia wizji nie } \\
\text { musi być wójt, często funkcje lidera przejmują inne osoby lub ich grupa, która wspomaga } \\
\text { wójta lub stanowi siłę prorozwojowową gminy. Zbiorowy lider spoteczności wiejskich jest } \\
\text { gwarantem, że wizja nie skończy się wraz z kadencją wójta, ale będzie siłą porywającą do } \\
\text { działłania i zmiany własnej gminy. }\end{array}$ \\
\hline
\end{tabular}




\begin{tabular}{|c|c|}
\hline Zespołowe uczenie się & $\begin{array}{l}\text { Zespołowe uczenie się jest czymś więcej niż tylko sumą wiedzy posiadanej przez } \\
\text { poszczególnych członków organizacji. Lider lub liderzy dają gwarancje zbiorowego } \\
\text { uczenia się gmin i w gminach. W nowoczesnych organizacjach (a do takich pretendują } \\
\text { coraz częściej także gminy wiejskie) zespoły, a nie jednostki, stanowią bowiem } \\
\text { podstawowe komórki uczące się. } \\
\text { Uczenie się w gminach wiejskich coraz częściej następuje w trakcie realizacji projektów } \\
\text { rozwojowych, szczególnie takich, w których wskazana jest współpraca urzędu gminy, } \\
\text { lokalnych liderów, organizacji społecznych. Uczenie się w takich sytuacjach często } \\
\text { obejmuje proces negocjowania i wypracowywania wspólnego stanowiska. }\end{array}$ \\
\hline Myślenie systemowe & $\begin{array}{l}\text { Myślenie systemowe pozwala każdemu pracownikowi dostrzegać, że nie jest tylko drobną } \\
\text { częścią systemu, ale ma wpływ na wszystko, co w organizacji się dzieje, a równocześnie } \\
\text { daje poczucie, że system to więcej niż tylko suma poszczególnych części. Wszystkie } \\
\text { wyróżnione przez P. Senge dyscypliny pozwalają organizacjom skuteczniej i sprawniej } \\
\text { funkcjonować poprzez świadomość ogromu własnej niewiedzy*. Myśląc systemowo, } \\
\text { gmina dostrzega korzyści rozwojowe wynikające z współrządzenia (opartego już nie tylko } \\
\text { na liderach indywidualnych, ale na liderze zbiorowym), partycypacji, ale co ważne, błędy } \\
\text { i niepowodzenia traktuje jako kolejny etap uczenia się, czyli rozwoju. }\end{array}$ \\
\hline
\end{tabular}

* „Im więcej się uczymy, tym lepiej zdajemy sobie sprawę z ogromu naszej niewiedzy”. P.M. Senge, Piąta dyscyplina. Teoria i praktyka organizacji uczacych się, wyd. V, Oficyna Ekonomiczna, Wolters Kluwer Polska, Kraków 2006, s. 23

Źródło: opracowanie na podstawie ibidem, s. 29 i nast., a także na podstawie obserwacji uczestniczącej autorki.

\section{Podsumowanie}

Sukces gospodarczy i związana z nim dywersyfikacja na obszarach wiejskich zależy od wielu czynników, wśród których można wyróżnić czynniki lokalizacyjne, społeczno-ekonomiczne i techniczno-organizacyjne ${ }^{33}$. Do tych ostatnich należy aktywność lokalna związana z programowaniem i pozyskiwaniem funduszy zewnętrznych.

Jak starano się wskazać w opracowaniu, w procesach programowania, procesach rozwojowych możliwe jest kilka modeli partycypacji obywateli, w tym szczególnie liderów lokalnych. Wydaje się, że im silniejsze więzi i zaufanie lokalne, ale wykraczające poza nasze najbliższe otoczenie (czyli rodzinę i znajomych), tym większa szansa na aktywne wykorzystanie społecznych czynników rozwoju. Na obszarach wiejskich można wskazać dwie główne formy liderów. Są to liderzy indywidualni, zazwyczaj formalni i coraz częściej obserwowane zjawisko liderów zbiorowych.

Przeprowadzona analiza wyraźnie wskazuje, że w gminach wiejskich, w których zachodzą dynamiczne procesy zmian modelu społeczno-gospodarczego, do odchodzenia od rolnictwa jako głównego kierunku rozwoju na rzecz przede wszystkim turystyki i usług okołoturystycznych nie wystarcza już tylko indywidualny lider lokalny. Wydaje się więc, że lider formalny (przede wszystkim wójt) jako samotny

33 J. Bański, K. Czapiewski, op.cit., s. 84. 
szeryf zarządzający gminą to obrazek odchodzący powoli (niestety zbyt powoli) do lamusa. Obecnie lider to grupa, która gwarantuje ciągłość procesu rozwoju w skali lokalnej bez względu na okoliczności, choćby takie jak wybory samorządowe. Ponadto lider zbiorowy to także gwarancja istnienia sieci powiązań, kanałów komunikacyjnych pomiędzy różnymi grupami społecznymi, czyli budowanie społeczeństwa obywatelskiego i wzmacnianie kapitału społecznego, tak istotnego jako nowoczesnego czynnika rozwoju.

\section{The role of local leadership in the processes of local development of small rural municipalities}

The paper focused on the role of the leader (individual and collective) in the processes of local development, especially in the programming of local development and community perceived as a learning organization. The analysis concerned the small rural municipalities. The studies allow to make the following conclusions:

- Economic success and associated with it the diversification of the rural areas depends on many factors, especially from local activity related to the programming and acquiring of external funds.

- A few models of public participation are possible in the programming and the developmental processes. It seems that the stronger social relations and local trust are in the communities, the greater chance is for active using of social development factors,

- Currently the most often existing local leader is a group, which guarantees continuity of the development on the local scale regardless of the circumstances,

- Local collective leader is also a guarantee for the existence of networks, communication channels between different social groups, that is building the civil society and strengthening of social capital,

- women play an increasingly important role among the local leaders.

\section{Le rôle du leader dans le processus de développement local}

Larticle aborde le problème du rôle que joue le leader (individuel et collectif) dans le processus de développement local, en particulier dans la planification du développement local et de la commune ("gmina») considérée comme une orga- 
nisation apprenante. L'analyse des petites communes rurales dans ce domaine a conduit aux conclusions suivantes:

- la réussite économique et la diversification dans les zones rurales dépendent de plusieurs facteurs, en particulier de l'activité locale qui est liée à la planification et à l'obtention de fonds externes,

- il y a plusieurs modèles possibles de participation des citoyens dans le processus de programmation et de développement; il semble que, plus les relations sociales et la confiance au niveau de la commune sont fortes, plus la probabilité de l'utilisation active des facteurs sociaux de développement est grande,

- actuellement, le leader local est le plus souvent un groupe qui garantit la continuité du développement à l'échelle locale dans toutes les circonstances,

- le leader collectif garantit également l'existence des liens, des canaux de communication entre les différents groupes sociaux, à savoir la construction d'une société civile et le renforcement du capital social,

- ce sont les femmes qui jouent un rôle de plus en plus important parmi les leaders locaux. 